\title{
Romanian legal rules and promotion of tourism in the community
}

\author{
Ion Tutuianu, "Vasile Alecsandri" University of Bacau, Romania
}

\begin{abstract}
:
In the context of EU enlargement, was normal and record tourism market development and competition. But tourism market works best when no participant's able to dictate terms. Otherwise, market monopolization occurs causing regression, generating serious disputes and contradictions. Therefore it proceeds to adoption and use of special legislative measures at national and community to counter these trends. The role falls to the State to be the organizer of the optimal conditions for tourism market development through the application of economic laws and removing barriers, promoting basic levers of the tourism market: demand, supply and competition as a way of confrontation between the owners of tourist offers and market demand .
\end{abstract}

\section{Keywords}

tourism, tourist, rules, community

\section{JEL Codes: K20, K33}

\section{Concepts of "Tourism and Tourist"}

The vast majority of dictionaries mentions occurring because of Etymologically the word "travel" comes from the English word 'tour' (travel) or to tour, to make the tour (to travel, make a journey of wandering), was created in England around the 1700 s, to describe the work of the voyage to Europe in general and France in particular. Also, turn the English term derives from the French word "tour" (travel, walk, move outdoors) was later adopted by the vast majority European languages, with the purpose of relaxation, recreation, leisure. French term ties are much deeper, it derived from the Greek word "Tournos" and from the Latin "turnus" meaning the whole circuit, unlike "peripliu" which refers to a circuit, but only at sea around an island, country, continent or around the Earth. Was acceptable and if Jewish origin of the word 'tour', in ancient Hebrew word 'tour' the concept of travel, discovery, recognition, mining.

Based on these speculations linguist, late last century and this century, the word gets real scientific definition.

Thus, tourism can be defined as a phenomenon related to leisure travel, knowledge of places and people. Making their appearance at the end of the nineteenth century tourist phenomenon is characterized by an accelerated growth in recent decades, reaching, at the beginning of XXI Century, a separate economic activity, which was constantly expanding. Increases in tourist activity started to appear and the first attempts to develop theoretical concepts that define the concepts of travel and tourism. Strong tourism development after 50 years has led to increasing concern to define the social and economic phenomenon of contemporary society, is currently make efforts to develop a 
definition that covers all of its specific elements which are consistent with changes in economic and social environment.

In this respect, the International Conference on tourism and tourism statistics, in Ottawa, in June 1991 gave a new interpretation of the basic concepts of tourism:

Thus, tourism can be defined as a business person who travels outside his usual environment for less than a specified period of travel whose principal purpose is other than the exercise of an activity remunerated from the place of visit. The term "normal environment" is meant to exclude travel and travel within the place of strength routine, and the phrase "less than a specified period of time" is meant to exclude long-term migration, and ultimately not the term "exercise of an activity remunerated from the place visited" is intended to exclude the phenomenon of migration for employment. Located in close interdependence with the term "tourism", the concept of "tourist" has received great attention of specialists in tourism, tourism experts of the National League considering any person who travels for 24 hours or more in a country his home country is not stable.

Widening international tourist traffic and shaping tourism as a separate economic activity has created global coordination problem of tourist activity. Close international collaboration in tourism, is simplified by the World Tourism Organization (O.M.T.) which took over in 1975 international positive experience of cooperation of the International Union of Official Travel Organizations (UIOOT). The fundamental objective of World Tourism Organization is

"Promote and develop tourism in order to contribute to economic expansion, international understanding, peace and prosperity, and the universal respect and observe human rights and fundamental freedoms without distinction of race, sex, language or religion.

In Romania, the most important role in coordinating activities at the national interest is the Ministry of Tourism.

Tourism is an activity that reflects and combined effort with several economic sectors. Given this, increased tourist activity causes the development of national economy (industry, agriculture, transport, trade) is Tourism is a more dynamic element of the global economic system.

Certainly the emergence of tourism activity creates jobs, both in specific areas of activity tourism and in other branches. Besides the obvious economic importance to them, and tourism are important socially, manifested as an active means of raising education and training, culture and people, recreation, relaxation, but recovery of strength and potential work, rest, motion, and climatic balneary treatments, helping to maintain physical health of the population.

\section{Forms of tourism}

With practice and trade wars that have pushed people beyond the influence of the social group which were started and the journey, thus locating it in the primitive village. Ancient Greeks desire was to facilitate and to gain security for visiting remote towns, contracts concluded by mutual visits, with people of the same occupation, using "sumbolonul", which is basically the precursor passport when you sail. To visit the holy places, healing baths and festive games held at regular periods, the travel between the Greek states were relatively large masses of people involved. In the Middle Ages more traveling merchants, ambassadors, priests and for religious pilgrims visiting the holy places. An impressive number of passengers was composed of scientists, artists, journeymen and students headed to universities and cultural centers, although the roads were unsafe. A French monk, named Aimeni Picaud wrote the first guide and trained in $1130 \mathrm{AD}$ pilgrims to reach Santiago de Compostela, along a road as less difficult. Developing trade led to the development of commercial travel and the consecration of trade 
routes, roads linking east with west Europe, the development of passenger traffic with the effect of development communications and the hospitality industry: in the sixth century and seven century and slower but in the eighth century, a very fast pace. Phenomenons being among which were imposed in the contemporary era tourist activity grew dramatically, representing a feature of the last century and especially the second half. Numerous studies have sought to detect trends in technical and economic development made in recent years highlighting the extraordinary range of technical changes, economic and social, in terms of years to come.

Potential natural and man-is "source" of various forms of tourism, which under the conditions of our country are united in a wide range.

In Romania the main categories of tourist resources and generate basic forms of Romanian tourism: mountain tourism (recreation, winter sports, hiking, speoturism, climbing, scientific knowledge, etc.), spa (spa treatment, climatic, rest), the season (rest, health spa, leisure, sports), hunting and fishing, tourism and leisure sports, cultural tourism (knowledge, educational and instructive), business, scientific, etc. Congress. The most comprehensive classification considered co retrieval enables both tourists and incentive travel preferences tourism and tourist-generating resources.

\section{Community and national rules on promoting tourism}

\section{EU tourism policy}

With the signing of the Accession Treaty, Romania entered its last stage its road to European Union apartentența. The consequence of this issue is on the one hand, there is commitment and complying with the Romanian authorities documents governing economic activities, political, social, and secondly, people are increasingly reporting the parameters that characterize the living conditions of residents of EU countries, advanced countries, which have a real market economy, and operating based on a true democracy.

In subsequent years, Romania had to meet all the requirements of integration, but only in areas of legislation and economics, but participants in economic life: producers, entrepreneurs, traders, service providers and ultimately consumers, to form a basis gâdire and action of subjects like European Union countries. An important role in the mechanism of competitive consumer plays. Once a country's economic development, consumer role becomes more complex he is confusing a number of imbalances that affect it in various aspects, but particularly in general economic and socially. By means provided by law, the state protects citizens as consumers in ensuring ${ }^{1}$ unhindered access to the necessary products and services, informing them complete and accurate correction of the characteristics of the goods / services, defense and enforcement of rights and interests of consumers against unfair practices.

Like other aspects of human life, tourism can not remain outside the scope of impact-induced change, the most important issue is how we use your free time has changed a lot, adding quantitative dimensions of being qualitative.

Tourism professionals need to adapt all this free time, change using imagination, creativity and innovation $^{2}$.

I have to stress role of tourism supply, demand supply is perceived as an "image" constructed by combining and synthesizing all information received by each tourist potential.

The European Union in hospitality and tourism activity is regulated by a series of directives, regulations, decisions and recommendations ${ }^{3}$.

Given the above, we intend to overview the current state of the problem of EU regulations

\footnotetext{
${ }^{1}$ Bojin E., Tribuna Economica,nr.3/1998,p.17.

2 Ileana Raducan, Dorina Tanasescu, Tribuna Economica, nr.3/1998, p. 35.

${ }^{3}$ Iuliana Mihalcea, Pachet documentar Targul National de Turism, Bucuresti,2002.
} 
and

Romania.

The European Commission has recognized 25 years ago still important role of tourism in the European economy, which is why more and more engaged in actions in support of other institutions like Parliament, European Council, the Committee and Economic and Social Committee.

After the first wave of accession on 1 May 2004, the number of EU Member States increased to 25 , its surface is increasing by $25 \%$ and $20 \%$ population. With this expansion manifested special interest for tourism in the newer states there also some obstacles such as low investment in this sector, infrastructure unsatisfactory terms of traffic, poor quality services, weakness in terms of marketing site. It is estimated that over the medium term new members will contribute considerably to change business travel in Europe.

\section{Issues of tourism and consumer rights}

Tourism fulfills multiple functions, namely: economic, social, political and even educational perspective is given to the objectives to be achieved in this area through tourism. Whatever attention should be focused on the consumer sector and its needs, and could achieve success by keeping the fundamental values that are distinct quality and related experiences, values that are constantly adapting to changing market trends. Understanding of consumer and its perpetual learning process and tourism demand is changing some of the prerequisites for success ${ }^{4}$.

The tourist industry based globalization increasingly computerized distribution and striving to provide quality products, therefore standardization is a necessity here, and could notice a risk which is the standardization of tourism, how appealing can experience travel, the variety and novelty to offer if it is subject to standardization? While tourism demand is increasingly fragmented and diferețiată (sports, theme trips, vacations ethnic, etc.).. Current consumer expects the same extent as such (which can be achieved through standardization) and differentiation. As consumers, tourists interests focuses, in particular around their physical safety and economic and legislative aspects. Tourists have generally a wide range of measures designed to protect consumer interests as a whole, and are covered by the Commission Directorate General for Health and Consumer Safety ${ }^{5}$.

While physical safety is an important issue, as nobody wants to think about holiday safety distinctly linked to the overall quality of service, many safety issues can be found in protection

consumer $^{6}$ legislation

In late 2000 the Council of Europe through political agreement and improved regulations on product safety measures that are available to consumers in the hotel. A field example is the Council Recommendation on fire safety system in hotels $(86 / 666 / \mathrm{CEE})$, where a set minimum requirements for fire safety in hotels.

In general, tourist interests are identical with those of any consumer and its interests are protected by law. However, the tourism activity are some aspects which need special protection, many details of the legislation in the EU Member States can be found in "travel packages", "holiday packages and packages for tours. From below we see how these regulations have as evolved concrete. Thus the Council Directive 90/314/EEC on the same level make rules and regulations

\footnotetext{
${ }^{4}$ Lohmann M., New Demand Factors in Tourism, European Forum for Tourism, Budapest,2004.

${ }^{5} \mathrm{http}$ :/europa.eu.int/comm./dgs/health_consumer/index_eu.htm.

${ }^{6}$ Tomescu Ada -Mirela, Botezat Elena, Tendencies of Consumer"s Protection in Romania, $14^{\text {th }}$ IGWT Congres, Beijing, 2004, p. 436.
} 
relating to "travel package" aiming to establish common minimum standards for consumer protection but also to develop general rules on contractual terms for "travel package . Also, the organizer of this package is required to demonstrate that it can repatriate the money and consumer insolvency. Sesns In this example, once a decision March 12, 2002, the European Court of Justice concluded that Article 5 of this Directive should be interpreted as: the consumer should be entitled to compensation if he suffers a loss due to the lack of an intangible benefit or improper benefits services included in the "package holiday".

More information about the rights of the citizen in the European Single Market space, or when a person tries to exercise their rights in the single market faces obstacles in the national government of a Member State, and the obstacles they consider unjustified, that citizen can call a system of free assistance.

The system consists of contact points for citizens. ${ }^{7}$

All tourists have been developed various travel guides, but also a web page dialog "Dialogue with Citizens".

Of particular importance in promoting products such as sustainable environmental guarantee is to make these products. Consumer familiarity with a particular brand can solve multiple problems in terms of quality, especially in an era of globalization is to say a "comfort" psychological even for a tourist to find a familiar brand to thousands of miles from home. Specific example here is the Blue Flag quality mark to be applied worldwide beaches that meet some standard indicators.

\section{Regulations on the promotion of tourism}

For the most part, the Romanian legislation is, at present, harmonized with EU directives provisions, established itself in this respect to recall that until now, the Romanian legislation has been harmonized with EU directives relating to: - general product safety

- misleading and comparative advertising

- providers liability for damages arising from defective services

- indication of prices, content and package travel, unfair terms in contracts, privacy, consumer health and safety.

To support the Romanian consumer, the state is bound by its institutions as to protect consumers from these unscrupulous organizations that ignoring the law and the unwritten rules of trade can afford to bring products to market with a low-quality products and even make life-threatening, health and consumer safety.

The most important measures have been identified, and must be taken in Romania to ensure that the market can be launched only those products that meet the requirements are:

-adoption of necessaryw legislation allowing sanctions against fraud and failure to comply with legal requirements;

- establishment of products comply with legal requirements;

- instruct inspectors to check products already on the market;

- establish controlø programs will have to indicate which products will be controlled within

a certain time and frequency and nature of control.

As the legislative work in recent years have adopted laws specifically to harmonize with EU regulations. Of this we can mention:

- HG 681/2001 on the establishment, organization and functioning of the Interministerial Committee for Market Surveillance and Consumer Products and Services (edit GD 449/2000);

Law on the approval of O.G. nr.58/2000 nr.37/2002 amending and supplementing

${ }^{7} \mathrm{http}$;/europa.eu.int/comm./dgs/internal_market/encpoints/index.htm; 
Ordinance 21/1992 on consumer protection, Directive 92/59/EC contains provisions on general product safety, and the Ordinance no.87 / 2000 on producer responsibility for damage caused by defective products based, harmonized with Directive 85/374/EC;

- Order nr.531/2001 of the President ANCP on the establishment, organization and functioning of the Committee on unfair terms; - Order nr.532/2001 NACP President on the establishment, organization and functioning of the Commission for product safety,

- Law no. Amendment of Law No. 65/2002. 193/2000 on unfair terms in contracts concluded between traders and consumers;

- Law no. 283/2002 amending and supplementing Law no. 148/2000 on advertising; - Law no. 322/2002 regarding the approval of Government Emergency Ordinance no. 146/2001 for completing Government Ordinance no. 21/1992 on consumer protection; - Order no. 516/2005 of 12/04/2005 to approve the marketing framework contract packages; - Government Decision no. 412/2004 on the organization and functioning of the Ministry of Transport, Constructions and Tourism, as amended, under the Government Ordinance. $107 / 1999$ on trading travel packages, approved with amendments by Law no. 631/2001, as amended, having regard to the proposals of the National Association of Travel Agencies;

- Government Decision no. 238/2001 on the conditions for patent licensing and tourism. Supervisory actions on consumer compliance laws on security products and services is the National Authority responsible for consumer protection and enforcement purposes in the field ANPC has taken on:

- Introducing the new media laws, to be known to both consumers and the operators concerned

of infringements of the legislation in force; - Development of specific control procedures for goods and services, which deals including the correct application of the laws in that field;

- Professional training of inspectors by considering the special cases, solved by law enforcement matters;

- Advising consumers and traders on specific issues of consumer protection. Although the Romanian market moving more and more travel guides, in English language sites offering tourist information and they are more numerous, and as sites to promote Romanian tourism resources in the languages of the world are increasingly numerous believe that information is not sufficient.

For example, concrete, Romanian tourist areas are tourist information points as little information or materials (maps, brochures, leaflets, guidebooks) are not sufficient.

\section{Conclusions}

As noted there are numerous data, publications, regulations currently relate to the tourism activity. Like other industries in Romania are good practices more or less known and applied.

Rather than being educated necunoscându their rights, Romanian consumer is subject to, and this time, to abuse.

A policy can support the government to correct these shortcomings by allowing the creation of free competition, but also the rules by which all tour operators and other service providers in this area strive to provide quality services, while leading to selection . Local Plan is another plan which should take something more than before, local authorities recovered it must understand that / interests and welfare of the communities they represent, it is intended to facilitate collaboration of all directly or collaterally interested in developing this work so special is that tourism in Romania still has untapped potential and a very strong economically. 
Besides all the rules to be adopted and respected, we must not forget that competition and the enlarged EU market will not resist than those who provide efficient and quality service. It says "no guarantee for success, but opportunities for everyone." 8

\section{Bibliografie}

1) Bojin, E. - Tribuna Economică, , 1998;

2) Răducan, I.; tănăsescu, D.; - Tribuna Economică, nr.31 1998;

3) Ban, O.; tomescu, A.; „Urban Touristic Resources. Oradea Municipality-Romania”, Opatija, Croatia, 2004;

4) Mihalcea, I. ; Pachet documentar Târgul National de Turism, Bucuresti, 2002;

5) $* * *$ Pagina web a CE - DG Enterprise/ Unit D.3 si Unit D. 2 ;

6) http://europa.eu.int/comm/dgs/health_consumer/index_en.htm

7) Tomescu, A.; Botezat, E.- "Tendencies Of Consumers' Protection în Romania", 14th IGWT Congress, Beijing, 2004

8) http://europa.eu.int/comm/dgs/health_consumer/index_en.htm;

9) http://europa.eu.int/comm/dgs/internal_market/en/cpoints/index.htm;

10) http://europa.eu.int/citizens;

11) http://europa.eu.int/comm/enterprise/services/tourism/tourismpublications/documents/befyou go.pdf;

\footnotetext{
${ }^{8}$ Lohmann M., Demand Factors in Tourism, European Forum for Tourism, Budapest, 2004.
} 